\title{
USE OF STREPTOMYCIN TO COMBAT CONTAMINATION OF TREPONEMA PALLIDUM SUSPENSIONS IN THE TPI TEST* $*$
}

\section{BY}

\author{
R. K. LEDBETTER, JR., AND R. J. CUMMING \\ U.S. Naval Medical School, Bethesda, Md
}

Since the middle of the 16th century when a virus was suggested as the causative agent of syphilis by Fracastoro (Pusey, 1933), many organisms have been labelled as responsible for the disease. For some time it was thought that syphilis was caused by a combination of micro-organisms, since the syphilitic individual was usually suffering from a mixed infection. This misconception was not

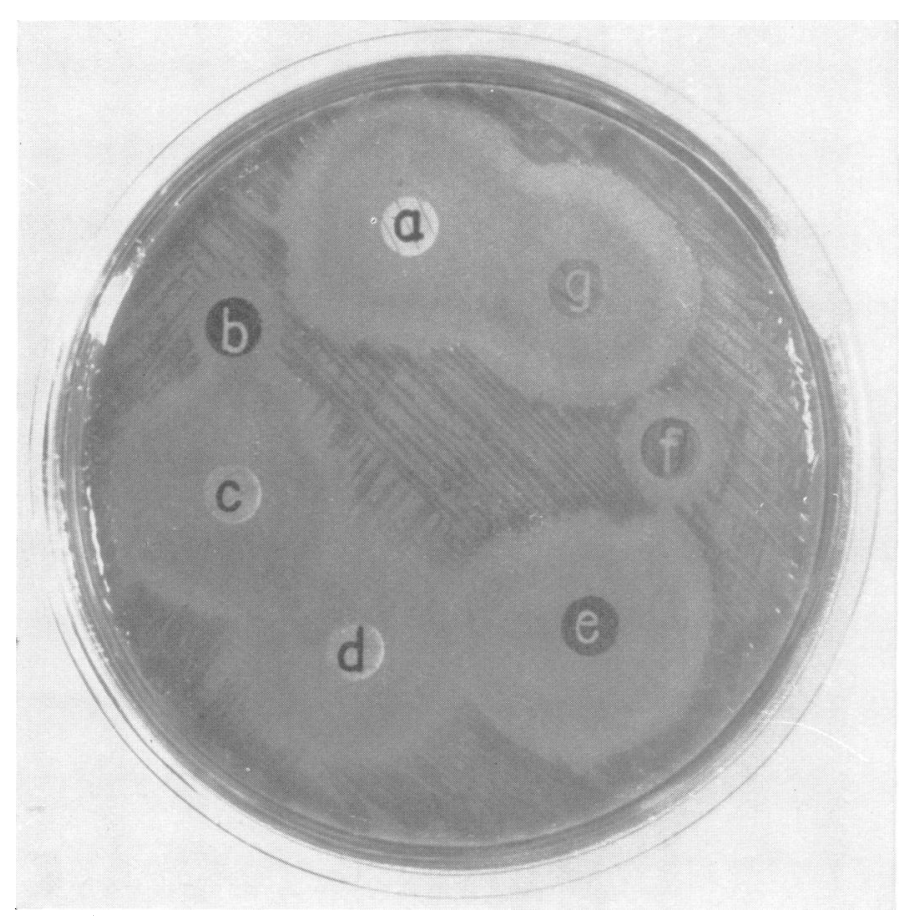

FIGURE.-Antibiotic sensitivity disks on blood agar plate.

Antibiotic

a. Aureomycin

b. Bacitracin

c. Chloramphenicol

d. Dihydrostreptomycin

e. Penicillin

f. Polymyxin B

g. Terramycin
Concentration $60 \mu \mathrm{g}$. $20 \mathrm{U}$.

$60 \mu \mathrm{g}$.

$100 \mu \mathrm{g}$.

$10 \mathrm{U}$.

$30 \mu \mathrm{g}$.

$60 \mu \mathrm{g}$. clarified until Schaudinn and Hoffmann (1905) described the spirochaete alone as the causative organism, thus ending a 400-year search. The identification of the specific organism inspired new enthusiasm, and many publications were made : Wassermann, Neisser, and Bruck (1906) described the diagnostic serum-complement reaction; Noguchi (1911) succeeded in cultivating Treponema pallidum "in vitro"; Nelson and Mayer (1949) described the Treponema pallidum Immobilization (TPI) test.

With the advent of the TPI test, it became necessary to maintain pure cultures of virulent $T$. pallidum for use as the antigen in the test mixture. The age-old problem of mixed cultures an contamination presented itself when many of the sera which were submitted to the laboratory for testing were contaminated. At first, Corning ultra-fine, sintered glass filters were used to sterilize the serum by filtration. Even though the filtration method was satisfactory, it was sometimes a lengthy process and much time had to be spent in cleaning and sterilizing the filters. In some instances there was an insufficient amount of serum to filter, and new specimens had to be requested at considerable expense.

It was desirable to find some better method for sterilizing the contaminated sera, which would eliminate the long filtering process, cleaning and sterilizing the filters, and the need for replacement samples. The logical answer seemed to be some selective antibiotic or other agent which would kill the contaminating organism without noticeable effect on the Treponema pallidum.

\footnotetext{
* Neceived for publication August 5, 1954.

$\dagger$ The opinions or assertions contained herein are the private ones of the writers and are not to be construed as official or reflecting the views of the Navy Department or the naval service at large.
} 
Several of the contaminated sera were streaked on blood agar and the contaminant cultured and identified. In the majority of the cases the intruder was Bacillus subtilis. The cultures from the blood agar plates were transferred, using heavy inoculums, to other blood agar plates, and these newly-inoculated plates were then overlaid with "Difco Bacto Sensitivity Disks" containing various concentrations of several antibiotics. They were then incubated at $37^{\circ} \mathrm{C}$. with readings made at 12,24 , and $48 \mathrm{hrs}$. Some of the antibiotics which showed the highest toxicity are shown in the Figure. The organism showed high sensitivity to aureomycin, chloramphenicol, dihydrostreptomycin, penicillin, and terramycin, but was only moderately sensitive to polymyxin $B$, and showed no sensitivity to bacitracin (Table I).

TABLE I

SENSITIVITY OF CONTAMINANT TO VARIOUS ANTIBIOTICS

\begin{tabular}{|c|c|c|c|c|c|}
\hline \multirow{2}{*}{\multicolumn{3}{|c|}{ Antibiotic }} & \multicolumn{3}{|c|}{ Sensitivity } \\
\hline & & & \multirow[t]{2}{*}{ Nil } & \multirow[t]{2}{*}{ Moderate } & \multirow{2}{*}{$\frac{\text { High }}{\times \times x}$} \\
\hline Aureomycin & . & . & & & \\
\hline Bacitracin & . & . & $\times \times \times$ & & \\
\hline \multicolumn{2}{|c|}{ Chloramphenicol } & . & & & $\times \times \times$ \\
\hline \multicolumn{2}{|c|}{ Dihydrostreptomycin } & .. & & & $\times \times x$ \\
\hline Penicillin. . & . & .. & & & $\times \times \times$ \\
\hline Polymyxin B & .. & .. & & $\times \times \times$ & \\
\hline Terramycin & $\ldots$ & . & & & $\times \times x$ \\
\hline
\end{tabular}

At this point it seemed that any of the five antibiotics for which the organism showed high sensitivity reactions would be acceptable ; however, the toxicity of these antibiotics for the treponeme was the next important fact which had to be determined. In order to determine this, 24 tubes were prepared as follows :

(a) 8 tubes containing sterile treponeme suspension;

(b) 8 tubes containing contaminated sera ;

(c) 8 tubes containing contaminated treponeme suspension.

Dilutions of the antibiotics indicated in the Figure were added to these tubes. On each of the three types of suspensions, an antibiotic-free control was run. All of the tubes, including the controls, were incubated at $35^{\circ} \mathrm{C}$. for $18 \mathrm{hrs}$ under anaerobic conditions as in the TPI test. The results are shown in Table II.

TABLE II

TREPONEMAL TOXICITY OF ANTIBIOTICS

\begin{tabular}{|c|c|c|c|c|}
\hline \multirow[b]{3}{*}{ Antibiotic } & \multirow{3}{*}{$\begin{array}{c}\text { Contam- } \\
\text { inated } \\
\text { Serum } \\
\text { Amount of } \\
\begin{array}{c}\text { Contam- } \\
\text { inate }\end{array}\end{array}$} & \multicolumn{3}{|c|}{ Treponeme Suspension } \\
\hline & & \multicolumn{2}{|c|}{ Contaminated } & \multirow{2}{*}{$\begin{array}{c}\text { Sterile. } \\
\text { Per cent. } \\
\text { Motile } \\
\text { Trepon- } \\
\text { emata* }\end{array}$} \\
\hline & & $\begin{array}{l}\text { Amount of } \\
\text { Contam- } \\
\text { inate }\end{array}$ & $\begin{array}{l}\text { Per cent. } \\
\text { Motile } \\
\text { Trepon- } \\
\text { emata* }\end{array}$ & \\
\hline 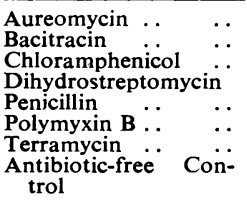 & $\begin{array}{l}\text { Slight } \\
\text { Moderate } \\
\text { Slight } \\
\text { NONE } \\
\text { Slight } \\
\text { Slight } \\
\text { Moderate } \\
\text { Gross }\end{array}$ & $\begin{array}{l}\text { NONE } \\
\text { Moderate } \\
\text { Slight } \\
\text { NONE } \\
\text { Slight } \\
\text { Moderate } \\
\text { Slight } \\
\text { Gross }\end{array}$ & $\begin{array}{r}10 \\
9 \\
33 \\
73 \\
8 \\
8 \\
6 \\
10\end{array}$ & $\begin{array}{r}0 \\
1 \\
13 \\
74 \\
4 \\
0 \\
12 \\
74\end{array}$ \\
\hline
\end{tabular}

\section{Conclusions}

Dihydrostreptomycin at a concentration of $100 \mu \mathrm{g}$. killed the contaminating organism without noticeable harmful effect on the viability of the Treponema pallidum, or on the residual complement reaction.

This work was completed during the summer of 1952 and has since been used by this laboratory routinely, under the above-mentioned conditions, with excellent results. It is felt that sufficient laboratory trials have been accomplished to prove this procedure to be satisfactory. The TPI laboratory at the Hôpital St. Lazare, Paris, has confirmed our findings.

The authors wish to express their appreciation to C. W. Norris, H.M.2, U.S.N., and C. W. Duff, H.M.1, U.S.N., for their able assistance.

\section{REFERENCES}

Nelson, R. A., Jr., and Mayer, M. M. (1949). J. exp. Med., 89, 369. Noguchi, H. (1911). J. exp. Med., 14, 99.

Pusey, W. A. (1933). "The History and Epidemiology of Syphilis", p. 68. Thomas, Springfield, Ill.

Schaudinn, F., and Hoffmann, E. (1905). Arb. GesundhAmte (Berl.), 22, 527.

Wassermann, A., Neisser, A., and Bruck, C. (1906). Dtsch. med. Wschr., 32, 745. 